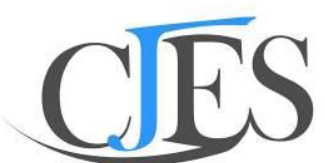

Cypriot Joumal of Educational Sciences

www.cjes.eu

\title{
Impact of public wellness, competitiveness, and government effectiveness on quality of education in Asian countries.
}

Ellisa Fitri Tanjung ${ }^{1}$, Universitas Muhammadiyah Sumatera Utara, Jl. Kapten Muchtar Basri No.3, Medan, Sumatera Utara 20238, Indonesia,

\section{Suggested Citation:}

Tanjung E. F., (2020). Impact of public wellness, competitiveness, and government effectiveness on quality of education in Asian countries. Cypriot Journal of Educational Science. 15(6), 1720-1731. https://doi.org/10.18844/cjes.v15i6.5329

Received from July 28, 2020; revised from October 23, 2020; accepted from December 28, 2020. (C)2020 Birlesik Dunya Yenilik Arastirma ve Yayincilik Merkezi. All rights reserved.

\begin{abstract}
The present study attempts to examine the impact of Public wellness, competitiveness and government effectiveness along with Literacy rate and Population growth on quality of education. For this research, the panel data has been collected over the period of 25 years for 10 Asian countries including World Bank and Global Economy data base. The data is specific to employed variables. Different statistical tests like Heteroskedasticity, Autocorrelation, Cross-section dependence and Multicollinearity, and the estimation of static and dynamic GMM were applied on the valid data. The results show that, public wellness, Government effectiveness, literacy rate and population growth significantly impact the quality of education in Asian Countries. Whereas the insignificant impact of competiveness was evidenced from outcomes of the research. This study is associated with all type of key implications in terms of theoretical, methodological, and practical perspectives as well. Lastly, various limitations have been given along with the recommendations for In-depth findings by the future researchers.
\end{abstract}

Keywords: public wellness, competitiveness, government effectiveness, quality of education, Asian countries.;

\footnotetext{
1 * ADDRESS FOR CORRESPONDENCE: Ellisa Fitri Tanjung, Universitas Muhammadiyah Sumatera Utara, Jl. Kapten Muchtar Basri No.3, Medan, Sumatera Utara 20238, Indonesia

Email Address: ellisafitri@umsu.ac.id
} 
Tanjung E. F., (2020). Impact of public wellness, competitiveness, and government effectiveness on quality of education in Asian countries. Cypriot Journal of Educational Science. 15(6), 1720-1731. https://doi.org/10.18844/cjes.v15i6.5329

\section{Introduction}

It is believed that education is the backbone of a country's prosperity, wellbeing of individual and a source of income. Nowadays, education is not only required but in addition focus is given to the quality of education. Among other regions, Asia is the largest and the most populated continent on this planet. It is accompanied by diverse situations of quality education in the region. In high income countries like China, Turkey, Maldives, the situation of literacy is much better as their literacy is above 90\%. In Middle-income countries like Pakistan, India and central Asian countries however, the situation of literacy is average and much more is needed be done. The situation of literacy is worst in low-income countries like Afghanistan and Iraq (Park, 2020). The literacy rate of Afghanistan is critically low (37\%) and girl-child education gives alarming statistics of $17 \%$, as per Transparency International Reports in 2018. The key factors that can influence the quality of education in any country are public wellness, competitiveness, and government effectiveness. Public wellness includes variety of other socioeconomic and health factors (Wilson-Anstey, Lambert, \& Krog, 2019; Burgos \& Bocco, 2020; Carranza Romero et al., 2020; Abulela \& Marwell, 2020; Akpur, 2020; Barkhuizen et al,. 2020; Bello \& John-Langba, 2020). The health of students is very critical as they spend almost 2 to 5 hours at their educational institutions. If the health of the student is not good then there will be increased chances of less attendance and lack of interest in their studies. Socioeconomic factors also contribute, since the students with better backgrounds will be able to focus more on their health and have regular check-ups than students with lesser income (Garg, Homer, \& Dworkin, 2019; Govender \& Govender, 2019; Hotar, 2020; Habanabakize, 2020; Kimanzi \& Gamede, 2020; Bello \& John-Langba, 2020; David \& Grobler, 2020; Hornung, 2020; Janssen, 2020; ). Another factor is competitiveness, which does not only motivate the student to achieve more but also motivates the institution as well. Competition among students and schools make the quality of education more effective and better(AlSartawi et al., 2019; Davis \& Wilson, 2019). The third factor that is critical for the quality education is the government effectiveness. Better education polices, implementation of those polices and the generation education funds ensure government effectiveness (Chiena, Linb, \& Chauc, 2020). It is the task of government to ensure the wellbeing of the students and families so that there will be no hurdle in gaining quality education (Gorczynski \& Aron, 2020). In developing countries, the drop out ratio of students after primary education is very common. Government should make policies in this regard and provide scholarships to ensure the enrolment of the students in the schools (Borda-Masa, et al. 2020; Codina et al., 2020). For higher education, funds for the research project should be generated so that the students can peruse their project without compromising on the quality (Rapacha, 2018; Sabbagh, Gedawy, Alshikhabobakr, \& Razak, 2017; Dalle et al., 2017)).

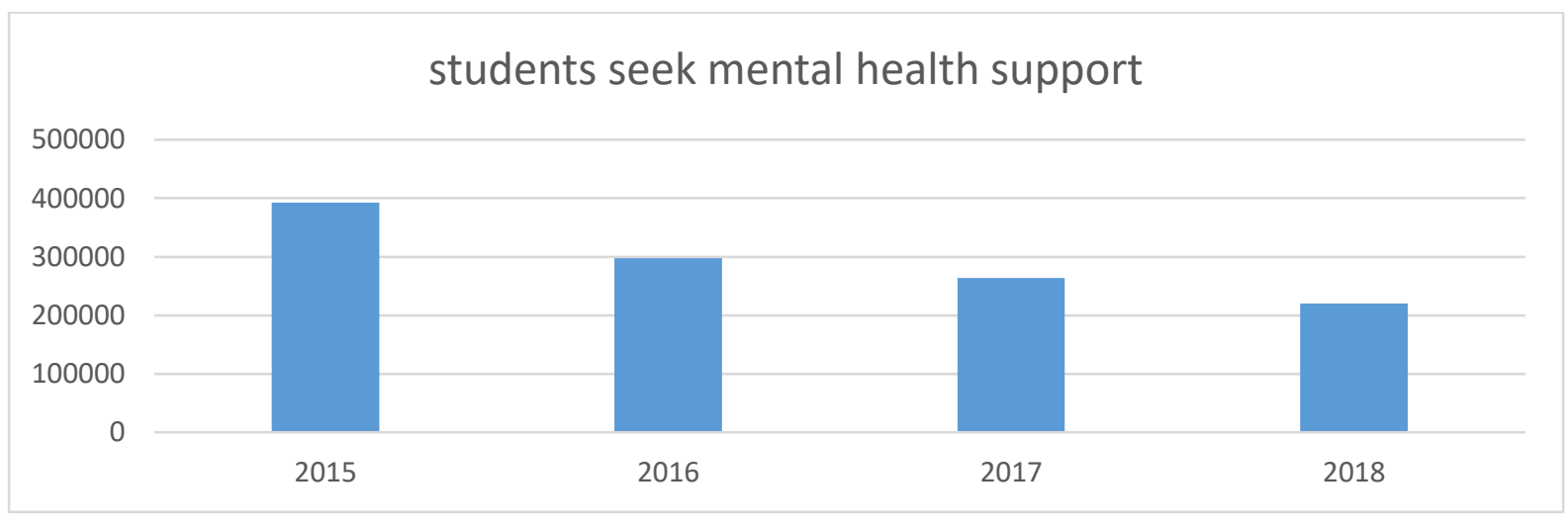

Figure 1. shows more students seek mental health support in 2016-2017

\subsection{Impact of public wellness on the quality of education}

The learning crisis in Asia especially in South East Asia is very critical. The factors that affect the quality of education in this region is poverty accompanied by the declined level of public wellness (Aytaç Demirçivi, 2020). According to The World Bank reports in 2015, the majority of the children in the 
South East Asia are malnourished and the root cause is poverty. Increasing enrolment in schools should not only be the concern by the government but also wellbeing of the child (Baharuddin \& Dalle, 2019). Zodpey et al., (2012) studied that due to immerse educational syllabus, economic pressure and keeping pace with the new scientific performances the health of the medical student's declined ( Pfeffer, 2015; Zeichner \& Conklin, 2017). This study was conducted in five Asian countries including India, Bangladesh, Vietnam, China and Thailand (Olasupo \& Idemudia, 2017; Rai, Dua, \& Yadav, 2019). The results of the survey suggested that the decline in health of the student is directly proportional to the quality of education (Zodpey et al., 2018). Zhou, Xin, \& Du et al. (2019), Suggested that in the past three decades, the migration of individuals from rural to urban areas is evident. This brings a lot stress to the students including mental and physical decline of health (Zhou, Xin, \& Du, 2019; Ozbey, 2020). Due to this, the children belonging to low-income backgrounds are gaining low quality of education and facing cognitive developmental issues. Decline in the mental and physical health decrease concentration in education (Dinç Aydemir \& Aren, 2017; Gong \& Yi, 2018; Muda, 2017; Muhle, 2020).

Patwa, Peverly et al. (2019), suggested that there should be a psychologist in every school to ensure the mental wellbeing of the children. In India, one third of the students live in the slums. These students got various diseases from their environment. These illnesses are hindrances in the quality of education (Patwa, Peverly, Maykel, \& Kapoor, 2019). Kok \& Low (2019) performed a study in Malaysia to evaluate the decline in mental health due to academic and economic stress. The results of the study reveal that the increased curriculum and increased expectation from the institution declines the health of the student. And later this factor contributes in the decline in the quality of education (Kok \& Low, 2019). The same situation was studied in Korea as well (Phosaly, Olympia, \& Goldman, 2019). Special children like the ones dealing with Autism, due to unavailability of educational institutes in the developing countries are factors that lead to the decline in the quality of education in the region ( Sağıroğlu \& Uzunboylu, 2018; Phosaly et al., 2019; Elsayed \& Salama, 2020). The first hypothesis is:

H1: Public wellbeing has positive impact on the quality of education.

\subsection{Impact of competitiveness on the quality of education}

Sulisworo (2016) studied the role of competitiveness in the quality of higher education in the East Asian countries. The study found out that, the competitiveness in the educational sector in the South Korea, Hong Kong and Singapore have invited various prestigious institutes of the world to open campuses in their country (Sulisworo, 2016; Udokang \& Odeyemi, 2020). Istvan et al. (2016), suggested that the more competitive the institution, the more students will apply for their programs. Lack of competitiveness decreases the quality of education and this will later result in the shortfall in applying students as happened in the developing countries of the Asia (Istvan, Darabos, \& Orsolya, 2016). Keser et al., (2012) suggested that the incorporation of new technology in the education sector is due to competition of educational institutes (Dalle \& Ariffin, 2018). This technology will further help in raising the economy. According to the study, tertiary education produces employees for both private and public-sector jobs in the country (Keser, 2015). According to the study, tertiary education produces both private and public-sector jobs. Quality of higher education has an impact on the competitiveness of both people and organizations from the point of view of the public domain. This will influence the students to get in to entrepreneurship leading to the economic progress of the country (Altuntepe \& Güner, 2013).

$\mathrm{H} 2$ : Competitiveness has significant impact on the quality of education.

\subsection{Impact of government effectiveness on the quality of education}

Siddique et al. (2016), assessed the impact of government effectiveness and impact of its polices in the SAARC countries (Siddique, Shehzadi, \& Shaheen, 2016; Alvi \& Rehan, 2020). The outcome of the study suggests that lack of government polices' effectiveness is declining the quality of education in South Asia. Sen et al. (2015), in the World bank report of the year 2014 suggested that higher 
education is highly influenced by the polices made by the government (Sen, 2015). The empirical findings of their study imply that after the completion of technical courses, teachers' confidences and pedagogical skills increased significantly and 70 percent teachers found the course useful for improving their pedagogical skills. The empirical studies also support the importance of technical training and technical courses in inculcating the technical skills in teachers to meet the dynamics of education standards. According to Dar, Jabeen, Jadoon, and Dar, (2016) faculty development programs and technical training of teachers raise the abilities and technical skills of the teachers. They used the survey data of 95 faculty members of various public sector universities. The study employed thematic analysis to analyse the results, which illustrates that faculty development programs, by providing technical training to teachers, improves the overall quality of learning in higher education (Isik \& Jallad, 2019). The third hypothesis is:

H3: Government effectiveness has significant impact on the quality of education.

\subsection{Objective}

Despite the various affords done by the governments of Asian countries, level of quality of education is declining in developing countries in Asia. To increase the quality of education, government of Asian countries are working on public wellness, competitiveness, and government effectiveness. This study has tried to fill lacunas in literature by conducting empirical research using panel data of Asian countries to explore the link between educational quality with government scholarship, technical training, and R\&D. A lot of work is done, and much more is needed in these factors to improve the quality of education. Based on the above material, the following are the key objectives as observed under current research.

1. Determining the public wellness on the quality of education in the selected Asian economies.

2. Analysing the impact of competitiveness on the quality of education in the selected Asian economies.

3. Investigating the impact of and government effectiveness on the quality of education in the selected Asian economies.

\section{Methodology}

\subsection{Data}

The collection of data is the foremost and vital step in the process of research as it enables the author to initiate the research. For determining the authentic results, the collection of accurate data is essential. Considering the significance of accurate and reliable data, the data of 10 Asian countries including Indonesia, India, Thailand, South Korea, Sri Lanka, Vietnam, Malaysia, Japan, china, and Bahrain over the period of 25 years has been collected by the current study from trustworthy and authentic sources. The database of World Bank and Global Economy Portal was utilized for gathering the information about the incorporated variables. The reliability of the collected data has been ensured as it effects the authenticity of the obtained results. The key variables of the study comprised of Public Wellness, Competitiveness, Government Effectiveness and Quality of Education.

\subsection{Model Specification}

The model specification is another vital step in the research process once the data has been collected. Firstly, the categorization of variables in terms of dependent, independent and control variables is done along with their units of measurement. The current study incorporated Quality of Education (QE) as the dependent variables, whereas Public Wellness (PW), Competitiveness (CO), and Government Effectiveness (GE) are included as independent variables. Similarly, the present study involves two control variables that is: Population Growth (PG) and Literacy Rate (LR). The mentioned variables are 
measured with different units as follows: The Government effectiveness is measured with the Government effectiveness index on a scale ranging from -2.5 to 2.5. The variable Competitiveness is measured by world economic forum index ranges form 1-7. The literacy rate is measured with the percentage of educated citizens and the population growth is measured in terms of annual percentage change. Likewise, the quality of education is measured by global competitiveness index on quality of education system with a scale of $1-7$. The following regression equation is formulated with the incorporation of the above-mentioned units and notations,

$$
Q E_{i t}=\alpha+\beta_{1} P W_{i t}+\beta_{2} G E_{i t}+\beta_{3} C O_{i t}+\beta_{4} L R_{i t}+\beta_{5} P G_{i t}+\varepsilon_{i t}
$$

In the above equation, QE shows quality of education, PW shoes public wellness, GE shows Government effectiveness, $\mathrm{CO}$ shows competitiveness. While LR denoted Literacy rate and PG denotes Population growth. $\varepsilon_{i t}$ is representing the error term.

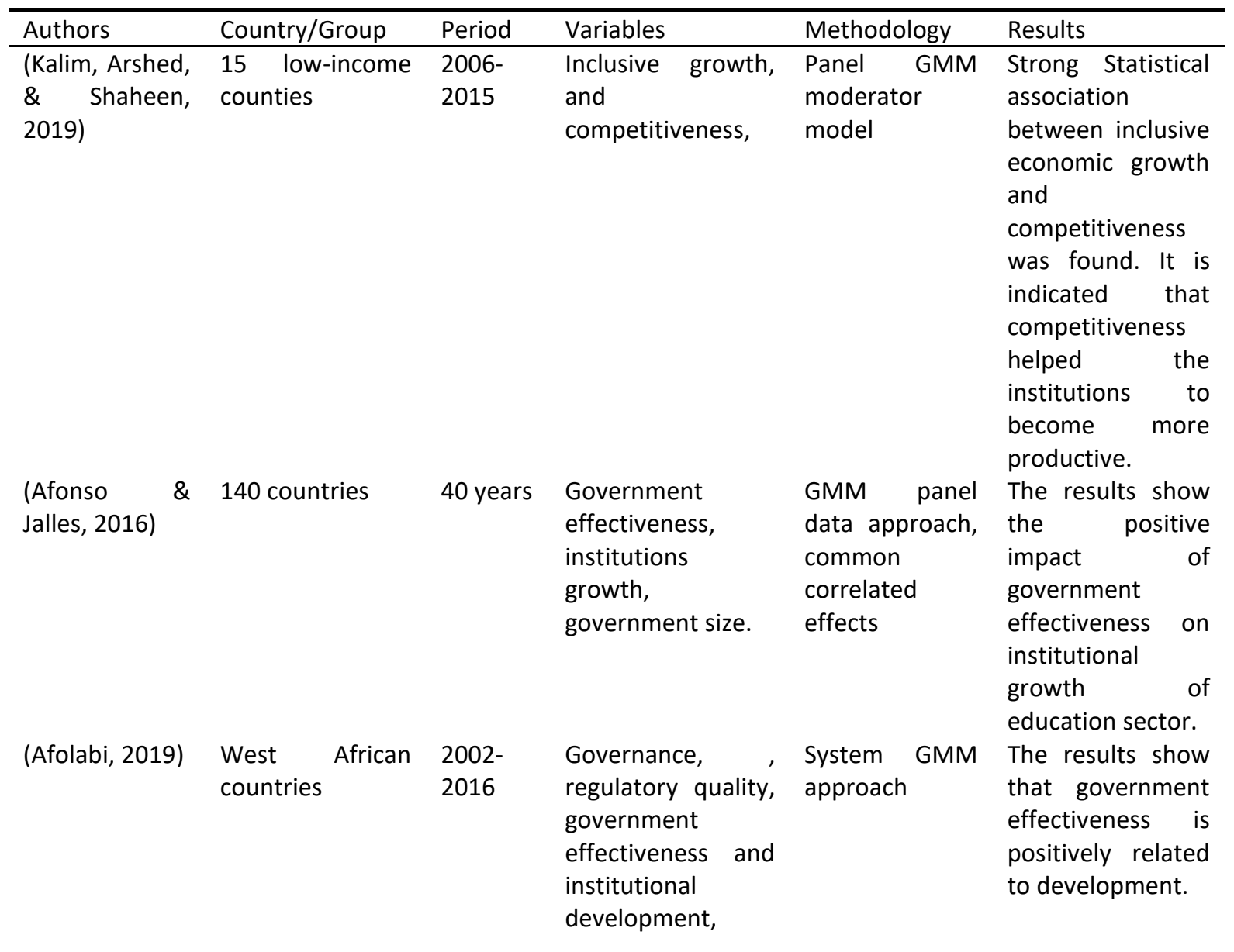

\subsection{Estimation Procedure}

The details of the applied estimations and procedures and approaches are discussed in this section. The applied test comprises of unit root test and General Methods of Movement (GMM) estimations.

\subsubsection{Application of Unit root test}

For the confirmation of stochastic attributes of the variables, in addition with their integration orders, the unit root tests of "Levin-Lin-Chu (LLC)" (Breitung \& Das, 2005)is applied in the current study. In comparison to the time series unit root tests, these tests have advantages of overcoming the problem related to size and power of technique of individual time series. Also, it is mentioned in the literature that for a standard normal distribution, the panel root test statistics is convenient. This test is the 
extended form of Dickey-Fuller unit root tests utilized in time series approach. The identification of null hypothesis is done based on unit root and non-stationary property of data. The rejection and acceptance of these hypothesis determines the result of unit root tests. In addition, it is assumed that, across the cross sections, the similar autoregressive process was followed. The following equation represents the structure of the unit root test:

$$
\Delta y_{i t}=\alpha_{i}+p y_{i, t-1}+\sum_{j=1}^{p_{i}} \alpha j \Delta y_{i, t-j}+\epsilon_{i, t}
$$

\subsubsection{Application of Diagnostic tests}

In order to address various issues in the data set and the model, this study has utilized "modified Wald and Breusch-Pegan/Cook Weisberg Heteroskedasticity test, Wooldridge test for autocorrelation, VIF test for multicollinearity and cross-section dependence test" of (Pesaran, 2004). In addition, for checking the possibility of any multicollinearity bias, the results of correlations among variables are examined.

\subsubsection{Application of system-GMM approach}

The generalized methods of moments are the general framework utilized for deriving estimators. It is based on the assumptions about the random variable moments to determine objective function (Blundell \& Bond, 2000). It is used for the estimation of dynamic models of panel data. The "GMMSYS estimator" is the system which contains the level and first difference equations. Which is the alternative of "standard first difference GMM estimator" (Arellano \& Bond, 1991). It is evidenced in the literature that the regression models of panel data are exposed to problems of heteroskedasticity, autocorrelation and cross section dependence along with multicollinearity. To address these problems of cross section dependence, autocorrelation, and heteroskedasticity, the model is tested for "modified Wald and Breusch-Pegan/Cook Weisberg heteroskedasticity test, Wooldridge test for autocorrelation, VIF test for multicollinearity and cross-section dependence test" of (Pesaran, 2004). Also, the correlation among variables is examined for determining the relationship among variables. Thus, the following equation has been incorporated for the application of GMM model:

$$
\vartheta_{i t}=\alpha_{i}+y_{i, t}+\sum_{p=1}^{p} B+\sum_{q=1}^{q} B+\sum_{r=1}^{r} B+E_{i, t}
$$

In the mentioned model, the quality of education of 10 Asian countries is represented with $\vartheta_{i t}$, the constant term is represented with ai. $\gamma \vartheta_{i, t-1}$ denotes the lag value of quality of education, $Z_{i t}$ represents the predictor variables, while $\epsilon_{i t}$ is the error term. In addition, the unobserved factors of quality of education are represented with $v_{i t}$ and $e_{i t}$ shows the idiosyncratic errors.

\section{Results}

\subsection{Results of Unit Root Test}

This study has applied the LLC test to test the null hypotheses of unit root against the presence of unit root in the series. When LLC test was applied, as shown from table 1 all the variables in the level series were found to be stationary except PG and LR which are non-stationary. But when the $1^{\text {st }}$ difference is applied, all of them become stationary. So, all these facts and results show that all the variables that are included in this study are stationary. 
Table 1. LLC unit root

\begin{tabular}{lll}
\hline Constructs & Level & 1 $^{\text {st }}$ difference \\
\hline PW & -2.633 & $-5.498^{* *}$ \\
CO & -3.983 & $-4.393^{* * *}$ \\
GE & -.359 & $-6.298^{* * *}$ \\
PG & $-4.237 *$ & $-7.583 * * *$ \\
LR & $-3.483^{*}$ & $-5.548 * * *$ \\
QE & -2.485 & $-9.348^{* *}$ \\
\hline
\end{tabular}

\subsection{Results of Diagnostic tests}

Various tests are applied under the present study. The results are presented in table 2 and 3 . The results show the significant heteroskedasticity levels among the variables, and also the cross-section dependence is observed.

Table 2. Diagnostic checks

\begin{tabular}{lll}
\hline HSK & $\begin{array}{l}\text { MW. Breusch- } \\
\text { Pagan/Cook- } \\
\text { Weisberg }\end{array}$ & $\begin{array}{l}\chi^{2-\text { value: } 9.13 * * /} \chi^{2-} \\
\text { value: } 4.98^{*}\end{array}$ \\
\hline AUTOCOR & Wooldridge & F-test $6.93^{*}$ \\
\hline CD dependence & Pesaran & Test scores: $2.042^{*}$ \\
\hline Multicollinearity & VIF & VIF Mean: 2.94 \\
\hline
\end{tabular}

Note: HSK means Heteroskedasticity, AUTOCOR: Autocorrelation

Table 3. Correlation Matrix

\begin{tabular}{lllllll}
\hline Variables & PW & CO & GE & PG & LR & QE \\
\hline PW & 1 & & & & & \\
CO & .548 & 1 & & & & \\
GE & .502 & .582 & 1 & & & \\
PG & .395 & .344 & .284 & 1 & 1 & .582 \\
LR & .492 & .394 & .399 & .283 & 1 \\
QE & .234 & .542 & .362 & .583 &. & \\
\hline
\end{tabular}

\subsection{PCSE estimation Results}

The literature emphasized the importance of "first-differenced GMM and "system GMM" approach (Blundell \& Bond, 2000). It is identified that the $1^{\text {st }}$ differentiated model is not effective in providing the accurate results in the presence of small sample size. And it is highlighted by Bond \& Windmeijer, 2002 that the system GMM application provides the accurate results with the high accuracy, due to the utilization of large number of instruments, and the connection in the levels of regression, with the regression in first-difference. In addition, the system GMM model is applied as it addressed the sample size bias along with the improved precision of the model. The two major techniques (static estimation and dynamic estimation) were estimated by the current study to mitigate the issues of cross section dependence, heteroskedasticity and determination of robust standard errors.

The static estimation by using "Prais-Winsten regression" was performed with "correlated PCSE and dynamic estimation" by utilizing the "one step system GMM estimation". It is required to incorporate the dynamic and static estimation in order to ensure that the findings are robust. The country and time fixed effects are applied for capturing the heterogeneity which is unobserved. The assumption 
of "PCSE estimation" is that across the panels, the disturbances are contemporaneously correlated and possess heteroskedasticity and have the ability to handle the panel which is unbalanced

Table 4 represents the GMM estimations both dynamic and static. It is indicated from the results that $\mathrm{PW}$ is significant in both dynamic and static estimations and indicating that public wellness has significant impact on quality of education. Similarly, it is shown that (GE) Government effectiveness also had a significant impact on the quality of education in Asian countries according to dynamic and static estimations. In the same way, dynamic and static estimations show that the variable (PG) Population growth and (LR), literacy rate have a significant impact on quality of education in selected countries of Asia. On the contrary, no significant impact of competitiveness level on the quality of education is observed from the results of both the estimations.

Table 4. Results from PCSE estimation

\begin{tabular}{lll}
\hline Dependent Variable $=$ QE & PCSE estimation & Sys-GMM estimation \\
\hline PW & $0.219^{* *}$ & $0.201^{* *}$ \\
& $(0.582)$ & $(0.282)$ \\
CO & 0.103 & 0.104 \\
& $(0.891)$ & $(0.768)$ \\
GE & $0.294^{* *}$ & $0.284^{* *}$ \\
PG & $(0.745)$ & $(0.683)$ \\
& $0.139^{*}$ & $0.140^{*}$ \\
LR & $(0.931)$ & $(0.485)$ \\
& $0.194^{* *}$ & $0.183^{* *}$ \\
Constant & $(0.438)$ & $(0.344)$ \\
$R^{2}$ & $0.482^{* *}$ & $0.492^{* *}$ \\
$N$ & $(0.632)$ & $(0.759)$ \\
$N$ & $0.638^{* *}$ & - \\
$N$ of Instruments & $(0.841)$ & - \\
$N$ & 250 & 248 \\
Arellano-Bond test for AR (1) (Pr W z) & - & 248 \\
Arellano-Bond test for AR (2) (Pr W $z)$ & - & 0.074 \\
Hansen test of overid restrictions & - & 0.438 \\
\hline
\end{tabular}

$N$ means number of observations.

\section{Discussion}

This study is implemented in Asian economies and for this purpose, the impact of Public wellness, competitiveness, and Government effectiveness on the quality of education. Also, the impact of control variables, that is Literacy rate and Population growth is also analysed. Multiple hypotheses have been formulated to investigate the relationships. For hypothesis testing system GMM approach was applied. It was assumed that the level of public wellness possessed by the citizens Asian countries have its positive and significant influence on the quality of education. This hypothesis was accepted as the wellness levels in terms of health, way of living and satisfaction with current human development policies, the quality of education system will be improved. The results are consistent with the findings of (Sun et al., 2017).

The author has tested hypothesis 2 and 3 and declared them as accepted since the effective governmental policies in the educational decisions like education budget, educational investment, 
development of educational institutes, expenditures on education infrastructure of a country determines the quality of the education system (Odhiambo, 2011). The results are consistent with the findings of (Solihin, Mursinto, \& Sugiharti, 2017). As the high literacy rate leads towards educated citizens and human capital and led to the overall improved education system of the country, the effective mechanism for increasing the literacy rate should be devised. These results are also in accordance with the previous studies (Dufera,2017; Yıldız, F. Ülkü, Cagdas \& Kayili, 2020)

\section{Conclusion}

The motive of the study is the investigation of factors that impact the quality of education in Asian countries. For this research, the panel data has been collected over the period of 25 years for 10 Asian countries from World Bank and Global Economic data base. The data is specific to employed variables. After the completion of data collection, several tests were applied in order to test the hypotheses using the system GMM approach. The tests include LLC unit root test, diagnostic tests of Heteroskedasticity, Autocorrelation, Cross-section dependence and Multicollinearity, and the estimation of static and dynamic GMM. The purpose of these tests were to examine the impact of incorporated variables on the quality of education.

\subsection{Implications}

The quality of education is the vital component for the growth of country as it determines the competitiveness of its citizens and enhances the chances of development of a country. In this study the determinants of educational quality in the region of Asia which was observed through the incorporation of public wellness, Government effectiveness and competitiveness level, literacy rate and population growth. Based on the research objective, the study embraces several theoretical, practical and policy making implications that will improve the education quality in the examined countries of Asia with the participation of citizens with high degree of wellness, effectiveness of government in educational policies and enhancement of literacy rate. The study will help future researchers in understanding the determinants for judging the quality of education throughout the world. Also, the study will guide the governmental authorities to revaluate their governance systems effectively for the education sector along with the focus on wellness of the citizens as their satisfaction with their wellbeing determines the smooth functioning of the overall education system. In addition, it is indicated that literacy rate determines the quality of education, it is suggested to devise policies for upgrading the education system and enhancing the literacy rate of the country.

\subsection{Limitations and Future research indications}

Like many other studies, this study is also not free from certain limitations and loopholes, which can be effectively filled by future researchers to improve the quality of their researches. The sample size of data can be increased to determine more comprehensive results. The study is concentrated on Asian countries only. The specific tests that were used in this study limits the scope of the study. For covering the stated limitations, the researchers can increase the sample size of the collected data. Any other region, Other than Asia can also be used along with panel data approach for increasing the study scope.

\section{References}

Abulela, M. A. A., \& Harwell, M. M. (2020). Data analysis: Strengthening inferences in quantitative education studies conducted by novice researchers. Educational Sciences: Theory and Practice, 20(1), 59-78. https://doi.org/10.12738/jestp.2020.1.005

Afolabi, J. O. (2019). The Impact of Governance on Economic Development in West Africa: A system GMM dynamic panel approach. Acta Universitatis Danubius. Economica, 15(3). https://www.ceeol.com/search/article-detail?id=854761 
Tanjung E. F., (2020). Impact of public wellness, competitiveness, and government effectiveness on quality of education in Asian countries. Cypriot Journal of Educational Science. 15(6), 1720-1731. https://doi.org/10.18844/cjes.v15i6.5329

Afonso, A., \& Jalles, J. T. (2016). Economic performance, government size, and institutional quality. Empirica, 43(1), 83-109. DOI: https://doi.org/10.1007/s10663-015-9294-2

Akpur, U. (2020). A systematic review and meta-analysis on the relationship between emotional intelligence and academic achievement. Educational Sciences: Theory and Practice, 20(4), 51-64. https://doi.org/10.12738/jestp.2020.4.004

Al-Sartawi, A. M. M., Badawi, S., Hanoon, A., Hamdan, A., Reyad, S., \& Razzaque, A. (2019). Entrepreneurship Education and Country Competitiveness: Avenues for Future Research in the Arab Countries. Paper presented at the International Conference on Innovation and Entrepreneurship.https://doi.org/10.34190/ECIE.19.006

Altuntepe, N., \& Güner, T. (2013). Türkiye'de istihdam-büyüme ilişkisinin analizi (1988-2011). Uluslararası Alanya Işsletme Fakültesi Dergisi, 5(1), 73-84. http://www.acarindex.com/dosyalar/makale/acarindex1423869036.pdf

Alvi, J., \& Rehan, M. (2020). Factors affecting mutual fund performance in Pakistan. Global Journal of Business, Economics and Management: Current Issues, 10(2), 124-143. https://doi.org/10.18844/gjbem.v10i2.4907

Arellano, M., \& Bond, S. (1991). Some tests of specification for panel data: Monte Carlo evidence and an application to employment equations. The review of economic studies, 58(2), 277-297. DOI: https://doi.org/10.2307/2297968

Aytaç Demirçivi, K. (2020). Personal factors predicting EFL Learners' writing anxiety. Global Journal of Foreign Language Teaching, 10(4), 257-267. https://doi.org/10.18844/gjflt.v10i4.5104

Baharuddin, B., \& Dalle, J. (2019). Transforming Learning Spaces for Elementary School Children with Special Needs. Journal of Social Studies Education Research, 10(2), 344365.https://www.learntechlib.org/p/216580/

Blundell, R., \& Bond, S. (2000). GMM estimation with persistent panel data: an application to production functions. Econometric reviews, 19(3), 321-340. https://doi.org/10.1080/07474930008800475

Bond, S. R., \& Windmeijer, F. (2002). Finite sample inference for GMM estimators in linear panel data models. https://papers.ssrn.com/sol3/papers.cfm?abstract id=311061

Barkhuizen, N., Lesenyeho, D., \& Schutte, N. Talent Retention Of Academic Staff In South African Higher Education Institutions. International Journal Of Business And Management Studies, 12(1), 191-207. https://www.ingentaconnect.com/content/sabinet/high/2008/00000022/00000002/art00014

Bello, P. O., \& John-Langba, J. (2020). University students and police legitimacy: The South African Police Service before the loudspeaker. International Journal of Business and Management Studies, 12(2), 306320.https://tijbms.org/index.php/ojs/article/view/30

Breitung, J., \& Das, S. (2005). Panel unit root tests under cross-sectional dependence. Statistica Neerlandica, 59(4), 414-433. https://doi.org/10.1111/i.1467-9574.2005.00299.x

Burgos, A. L., \& Bocco, G. (2020). Contributions to a theory of rural innovation. Cuadernos de Economía, 39(79), 219-247.http://dx.doi.org/10.15446/cuad.econ.v39n79.74459

Carranza Romero, J. E., González Espitia, C. G., \& Bocanegra Ochoa, G. E. (2020). The effect of economic activity on homicidal violence: New evidence for Colombia based on panel data. Cuadernos de Economía, 39(79), 355-388. http://dx.doi.org/10.15446/cuad.econ.v39n79.43049

Codina, N., Pestana, J. V., \& Stebbins, R. A. (2020). Fitness Training As a Body-Centered Hobby: the Serious Leisure Perspective for Explaining Exercise Practice. 29, 73-81.https://ddd.uab.cat/record/225795

Dalle, J., \& Ariffin, A. M. (2018). The Impact of Technologies in Teaching Interaction Design. 10(Special Issue 04Special Issue), 1779-1783.http://eprints.ulm.ac.id/id/eprint/7760

Dar, S., Jabeen, N., Jadoon, Z. I., \& Dar, I. S. (2016). Faculty Development Programs and Their Effect on Individual and Organizational Performance in Pakistan. Pakistan Vision, 17(2). https://search.proquest.com/openview/9d59658976b2faae3d112fbcaa8f4b82/1?pqorigsite=gscholar\&cbl=1616339

Davis, E. R., \& Wilson, R. (2019). "Not so globalised": contrasting media discourses on education and competitiveness in four countries. Journal of Asia Business Studies, 13(1), 155-176. https://doi.org/10.1108/OTH-07-2019-0042

David, O. O., \& Grobler, W. (2020). Age Progression, Social Interventions And Food Insecurity In South Africa: Logistic Regression Analysis. The International Journal Of Social Sciences And Humanity Studies, 12(2), 289-305.https://search.proquest.com/docview/2405906127?pqorigsite $=$ gscholar \&fromopenview=true

Dinç Aydemir, S., \& Aren, S. (2017). Do the effects of individual factors on financial risk-taking behavior diversify with financial literacy? Kybernetes, 46(10), 1706-1734. https://doi.org/10.1108/K-10-2016-0281 
Tanjung E. F., (2020). Impact of public wellness, competitiveness, and government effectiveness on quality of education in Asian countries. Cypriot Journal of Educational Science. 15(6), 1720-1731. https://doi.org/10.18844/cjes.v15i6.5329

Dufera, D. (2017). Population growth as an impediment to the realization of Universal Primary Education in Ethiopia. The Ethiopian Journal http://213.55.95.79/index.php/EJE/article/view/480

Elsayed, M., \& Salama, R. (2020). Educational games for miss-concentration students (ADHD students). International Journal of Innovative Research in Education, 7(1), 26-31. https://doi.org/10.18844/ijire.v7i1.4762

Garg, A., Homer, C. J., \& Dworkin, P. H. (2019). Addressing social determinants of health: challenges and opportunities in a value-based model. Pediatrics, 143(4), e20182355. https://pediatrics.aappublications.org/content/143/4/e20182355

Gong, T., \& Yi, Y. (2018). The effect of service quality on customer satisfaction, loyalty, and happiness in five Asian countries. Psychology \& Marketing, 35(6), 427-442. https://doi.org/10.1002/mar.21096

Govender, R. G., \& Govender, D. W. (2019). Learning Geometry Online: A Creative Individual Learning Experience. International Journal of eBusiness and eGovernment Studies, 12(2), 151165.https://doi.org/10.34111/ijebeg.202012205

Hotar, N. (2020) Herd Behavior In Terms Of Social Psychology: The Example Of Crypto Asset Markets. International Journal Of Ebusiness And Egovernment Studies, 12(1), 79-90.https://doi.org/ 10.34111/ijebeg.202012106

Hornung, J. J. (2020). Comments on "Ornitocheirus hilsensis" Koken, 1883 - One of the Earliest Dinosaur Discoveries in Germany. Palarch's Journal of Vertebrate Palaeontology, 17(1), 112.https://archives.palarch.nl/index.php/jvp/article/view/2

Habanabakize, T. (2020). Assessing The Impact Of Interest Rate, Catering, And Fast-Food Income On Employment In The Social Services Industry. International Journal Of Economics And Finance, 12(2). https://doi.org/ 10.34109/ijefs.202012218

Isik, B., \& Jallad, S. T. (2019). The potential of social media and nursing education: E-professionalism, nurse educator-learner role, benefits and risks. New Trends and Issues Proceedings on Advances in Pure and Applied Sciences, (11), 30-38. https://doi.org/10.18844/gipaas.v0i11.4310

Istvan, L., Darabos, É., \& Orsolya, N. (2016). Competitiveness - higher education. Studia Universitatis Vasile Goldis Arad, Seria Stiinte Economice, 26. https://doi.org/10.1515/sues-2016-0002

Janssen, R. (2020). The Pleated Dress of Nywty.-Palarch's. Journal of Archaeology of Egypt/Egyptology, 17(1), 111.http://web.a.ebscohost.com/ehost/pdfviewer/pdfviewer?vid=0\&sid=71dd98c7-ba69-4553-a0e30923255941c5\%40sessionmgr4006

Kalim, R., Arshed, N., \& Shaheen, S. (2019). Does competitiveness moderate inclusive growth: A panel study of low-income countries. Competitiveness Review: An International Business Journal, 29(2), 119-138. https://doi.org/10.1108/CR-11-2017-0074

Keser, H. Y. (2015). Effects of higher education on global competitiveness: reviews in relation with european countries and the middle east countries. Annals of'Constantin Brancusi'University of Targu-Jiu. Economy Series, 1(1). https://econpapers.repec.org/article/cbujrnlec/y 3a2015 3av 3a1i 3ap 3a58-68.htm

Kimanzi, M. K., \& Gamede, V. W. (2020). Embracing The Role Of Finance In Sustainability For Smes. International Journal Of Economics And Finance, 12(2), 453468.https://sobiad.org/eJOURNALS/journal IJEF/archieves/IJEF-2020-2 ek/mk-kimanzi.pdf

Kok, J. K., \& Low, S. K. (2019). Risk factors contributing to vulnerability of mental health disorders and the protective factors among Malaysian youth. International Journal of School \& Educational Psychology, 7(2), 102-112. https://doi.org/10.1080/21683603.2018.1499573

Muda, I. (2017). User impact of literacy on treatment outcomes quality regional financial information system. Management Dynamics in the Knowledge Economy, 5(2), 307-326. https://ideas.repec.org/a/nup/jrmdke/v5y2017i2307-326.html

Muhle, T. C. (2020). Single-parenting influence on child's academic performances at MutareJunior School, Zimbabwe. Global Journal of Psychology Research: New Trends and Issues, 10(2), 233-246. https://doi.org/10.18844/gjpr.v10i2.4835

Odhiambo, G. O. (2011). Higher education quality in Kenya: A critical reflection of key challenges. Quality in Higher Education, 17(3), 299-315. https://doi.org/10.1080/13538322.2011.614472

Olasupo, M. O., \& Idemudia, E. S. (2017). Socio-economic and socio-demographic determinants of quality of life among young adults in South West Nigeria. Gender and Behaviour, 15(4), 9997-10009. https://hdl.handle.net/10520/EJC-c1e483f6f

Ozbey, A. (2020). Human values and psychological well-being of gifted/talented students and their peers with average development. Global Journal of Guidance and Counseling in Schools: Current Perspectives, 10(2), 64-78. https://doi.org/10.18844/gigc.v10i2.4656 
Tanjung E. F., (2020). Impact of public wellness, competitiveness, and government effectiveness on quality of education in Asian countries. Cypriot Journal of Educational Science. 15(6), 1720-1731. https://doi.org/10.18844/cjes.v15i6.5329

Park, K. (2020). Trend of income inequality in Asia and effects of education. Contemporary Educational Researches Journal, 10(2), 42-59. https://doi.org/10.18844/cerj.v10i2.4681

Patwa, S. S., Peverly, S. T., Maykel, C., \& Kapoor, V. (2019). Roles for school psychologists in the challenging Indian education landscape. International Journal of School \& Educational Psychology, 7(2), 94-101. https://doi.org/10.1080/21683603.2019.1570886

Pesaran, M. H. (2004). General diagnostic tests for cross section dependence in panels. https://doi.org/10.1002/jae.616

Pfeffer, F. T. (2015). Equality and quality in education. A comparative study of 19 countries. Social science research, 51, 350-368. https://doi.org/10.1016/i.ssresearch.2014.09.004

Phosaly, L., Olympia, D., \& Goldman, S. (2019). Educational and psychological risk factors for South Korean children and adolescents. International Journal of School \& Educational Psychology, 7(2), 113-122. https://doi.org/10.1080/21683603.2019.1578709

Rai, K., Dua, S., \& Yadav, M. (2019). Association of Financial Attitude, Financial Behaviour and Financial Knowledge Towards Financial Literacy: A Structural Equation Modeling Approach. FIIB Business Review, 8(1), 51-60. https://doi.org/10.1177\%2F2319714519826651

Rapacha, L. (2018). Aspects of Federalism Implementation for Development and Prosperity. Molung Educational Frontier, 8, 61-76. https://doi.org/10.3126/mef.v8i0.22441

Sağıroğlu, N., \& Uzunboylu, H. (2018). Analysis of the published articles related to autism in Turkey: A model proposal for students: Türkiyede yayınlanan otizimle ilgili makalelerin incelenmesi: öğrencilere yönelik bir model önerisi. Journal of Education and Special Education Technology, 4(1), 14-23. https://doi.org/10.18844/jeset.v4i1.4105

Sen, K. (2015). Governance and development outcomes in Asia. In Governance in Developing Asia: Edward Elgar Publishing.https://doi.org/10.4337/9781784715571.00012

Siddique, H. M. A., Shehzadi, I., \& Shaheen, A. (2016). The impact of governance and institutions on education and poverty alleviation: a panel study of SAARC economies. https://mpra.ub.uni-muenchen.de/71248/

Solihin, A., Mursinto, D., \& Sugiharti, L. (2017). Efficiency and Effectiveness of Government Expenditure on Education at Districts/Cities Level in East Java Indonesia. Asian Social Science, 13(8), 91. https://doi.org/10.5539/ass.v13n8p91

Sulisworo, D. (2016). The Contribution of the Education System Quality to Improve the Nation's Competitiveness of Indonesia. Journal of Education and Learning, 10(2), 127-138. https://doi.org/10.11591/edulearn.v10i2.3468

Sun, J., Ma, J., Hu, G., Zhao, Q., Yuan, C., Si, W., . . . Liu, Y. (2017). Welfare, wellness, and job satisfaction of Chinese physicians: A national survey of public tertiary hospitals in China. The International journal of health planning and management, 32(3), 270-284. https://doi.org/10.1002/hpm.2420

Udokang, A. E., \& Odeyemi, J. B. (2020). Empirical study of the effect of type of family and extra lesson on students' academic performance: A case study of some selected schools in Kwara State, Nigeria. New Trends and Issues Proceedings on Humanities and Social Sciences, 7(3), 94-103. https://doi.org/10.18844/prosoc.v7i3.5238

Wilson-Anstey, E., Lambert, W. M., \& Krog, H. (2019). Wellness for All: Diversity, Challenges, and Opportunities to Improve Wellness for Medical Students. In Medical Student Well-Being (pp. 125-153): Springer.https://doi.org/10.1007/978-3-030-16558-1 7

Yildiz, F. Ülkü, Cagdas, A. ., \& Kayili, G. . (2020). The effectiveness of the Montessori training programme for mothers: A2-year follow-up. Contemporary Educational Researches Journal, 10(4), 144-156. https://doi.org/10.18844/cerj.v10i4.5277

Zeichner, K. M., \& Conklin, H. G. (2017). Beyond knowledge ventriloquism and echo chambers: Raising the quality of the debate in teacher education. In The struggle for the soul of teacher education (pp. 103-138): Routledge.https://www.taylorfrancis.com/chapters/beyond-knowledge-ventriloquism-echochambers-kenneth-zeichner-hilary-conklin/e/10.4324/9781315098074-5

Zhou, Z., Xin, T., \& Du, L. (2019). Floating childhoods: Psychological and educational adaptations of migrant children in China. International Journal of School \& Educational Psychology, 7(2), 72-82. https://doi.org/10.1080/21683603.2019.1570884

Zodpey, S., Lumbiganon, P., Evans, T., Yang, K., Ha, B. T. T., Negandhi, H., . . Al-Kabir, A. (2018). Assessment of health professional education across five Asian countries-a protocol. Human resources for health, 16(1), 52. https://doi.org/10.1186/s12960-018-0316-6 